\title{
Synergism of Hypothyroidism and Hyperprolactinemia to impact on efficiency of menstrual cycle and ovulatory status
}

* NASSER NAFAA ABRAHEM

**SAAD HASSAN DREIJ

*Mahdi Saber Al-Deresawi

*Biology Department, College of Science, University of Wasit

**Ministry of Education / Directorate of Education - Dhi Qar

\section{Abstract :}

This study aimed to determine the relationship of thyroid hormone disturbance and prolactin over production to impact on the menstrual irregularities anovulation .This study were carried out in Al-Karama teaching hospital and included (47) primary infertile women, (30) of them were with hypothyroidism, the patients aged between (18-40). This study extended from February to June 2017.

The hormonal assay of TSH, FT3, FT4 ,FSH , LH and PRL that revealed :There were high significantly $(\mathrm{p}<0.01)$ increased in TSH concentrations , significantly $(\mathrm{p}<0.05)$ decreased in levels of FT3 and FT4.

Gonadotropins hormones recorded significantly $(\mathrm{p}<0.05)$ decreased in levels of FSH and non significantly increased in levels of LH. Prolactin concentrations that obtained revealed to significantly $(\mathrm{p}<0.05)$ increased in patients with hypothyroidism . This study reported there were (70\%) of hypothyroidism patients with menstrual disturbance.

We concluded, that hypothyroidism and Hyperprolactinemia commonly related and synergized to menstrual irregularities and ovulatory failure.

Key word: Infertile, anovulation, hypothyroidism, Hyperprolactinemia 
تاثير تآزر القصور الدرقي وفرط هرمون الحليب على كفاءة الدورة الشهرية وحال التبويض

مهذي صبر الدربساوي

كلية العلوم / جامعة واسط
سعد حسن دريج

وزارة التربية / مديرية نربية ذي قار
ناصر نافع ابراهيم

كلية العلوم / جامعة واسط البر

الخلاصة :

هدفت هذه الدراسة الى التحري عن علاقة الاضطراب الهرموني للارقية وفرط انتاج هرمون الحليب وتأثيرهما على اضطراب الدورة الثهرية وعدم التبويض • جمعت العينات من مسنشفى الكرامة التعليمي في محافظة واسط وتضمنت (V乏) امرأة تتراوح اعمارهن بين 1 1 - ، ـ سنة ويعانين من عدم الانجاب الاولي ، ثلاثون منهم يعانون من قصور الغدة الدرقية .

التحليل الهرموني للهرمون اللوتيني (LH) ) ، الهرمون المنبه للجريب (FSH) ، الثايروكسين (FT4) ، تراي ايودوثيريونين (FT3) ، الهرمون المنبه للدرقية ( TSH) وهرمون الحليب (PRL) يؤشر بان هناك

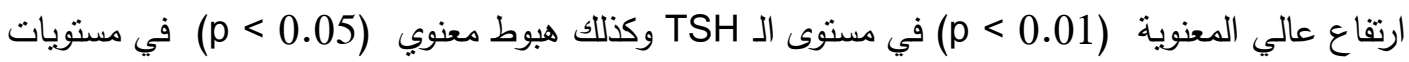
هرمونات الـ FT3 و FT4 ـ كما سجلت هرمونات القند انخفاضا معنويا في مستوى هرمون الـ FSH وكذلك ارتفاعا غير معنويا في مستوى الـ LH . وسجل هرمون الحليب PRL ارتفاعا معنويا مريضات قصور الغدة الدرقية . بينت الدراسة ايضا بان هناك • \&\% من النساء اللواتي بعانين من قصور الغدة الدرقية كان لايهن اضطرابا بالدورة الثهرية .

نستتنج من هذه الدراسة بان التآزر بين قصور الغدة الدرقية وفرط انتاج هرمون الحليب يؤدي الى دورة شهرية

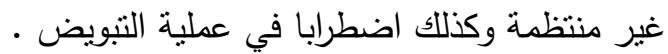




\section{1:- Introduction :}

Hypothyroidism is the most common pathological hormone deficiency caused by a primary process that produces insufficient amounts of thyroid hormone. Secondary hypothyroidism occurs when there is a lack of thyroid hormone secretion due to enough secretion of either thyroid stimulating hormone (TSH) from the anterior pituitary of and or thyrotropin-releazing hormone (TRH) from the hypothalamus [1].

Community studies of hypothyroidism prevalence determining thyroid disease is much more common in women than in men (2-8) times higher in females because the thyroid should more frequently to be abnormal in women and also in prepubertal females is not clear [2].

Thyroid disease not only occurs more commonly in women but also interferes with the physiology of the reproduction; both hyperthyroidism and hypothyroidism have significant effects on estradiol and androgen metabolism, menstrual function and fecundity [3].

The "prevalence of hypothyroidism in the population of reproductive age defined as an abnormally elevated TSH concentration, ranging from 2 to $4 \%$ [4]. The effect of hypothyroidism on the menstrual cycle has been known since 1950 . Hypothyroidism in adult female often results in changes in cycle length and blood flow . In older series, menorrhagia was the most prevalent symptom and occurred in (60\%) of overt hypothyroid women" [5]. Complications of pregnancy that are related with maternal hypothyroidism include gestational hypertension, placental cease, preterm delivery, spontaneous miscarriage, low birth weight and fetal distress[6].

Hypothyroidism may cause of failure of sex hormone by defecting the function of hypothalamo-pituitary ovary axis .Thus, a clinical pattern is very associated with menstrual disturbance, unovalatory, miscarriage and complications of pregnancy[7]. Researcher reported the Hyperprolactinemia that causes by increase of TRH levels and changing in gonadotropins- releasing hormone $(\mathrm{GnRH})$ pulsatile secretion resulting in delay of $\mathrm{LH}$ response and defect of corpus luteum [8]. 
The aims of this study were to detection the impact of hypothyroidism and prolactin overproduction on women infertility and determination the synergistic of thyroid hormone, prolactin, FSH and LH levels to impact on ovulatory .

\section{3:-Materials and Methods}

\section{3:1:- Subjects}

Two study groups have been included in this study :

\section{3:1:1- Patients group :}

The cases consisted of (47) women subjects who were suffering from primary infertility, the samples were collected from Al-Karama teaching hospital in Wasit province, This study extended from February to June 2017.

"The cases were selected over a period of four months. The inclusion criteria for the selection of cases were diagnosis of primary infertility, age between 18-40 years and duration of marriage more than 12 month". In this study we excluded 17 case that suffering from another causes of infertile and finally this study included 30 patient with hypothyroidism .

\section{3:1:2- Control group :}

Control group consisted of ten healthy fertile women which chosen dependent on the next criteria : Normal menstrual cycle (26 to 30 days), age 18 - 40 years, no history of endocrine disorders and "no use of oral contraceptives"[9].

\section{3:2:- Sample collection :}

Blood sample of patients and control group were collected during the follicular phase $(3,4$, or 5 day). Venous blood sample $(3 \mathrm{ml})$ was collected from each women . The serum collected by putting the blood samples in a clean plain plastic tube and allowed to clot at $37 \mathrm{C}$ for $30 \mathrm{~min}$ before centrifugation. The tubes centrifuged at $5000 \mathrm{rpm}$ for 5 minutes, "serum was collected and kept in freezer until used". 


\section{3:-Hormonal assay:}

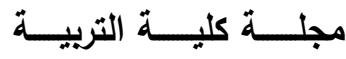

"Hormonal test was performed by using Addendum-Mini VIDAS apparatus (VIDAS) BioMerieux Company, France, through an enzyme linked fluorescent assay" (ELFA) technique in laboratories of Al-Karama teaching hospital .

\subsection{1:-Principle of technique :}

"VIDAS is an automated quantitative test for use on the VIDAS instrument for the quantitative measurement of serum using the ELFA technique". Solid phase receptacle (SPR) serves as the solid phase as well as the pipetting device for the assay. Reagents are ready to use and all of the assay steps were carried out automatically. The test principle of estimation of PRL and TSH linked an enzyme immunoassay competition method with a final fluorescent detection (ELFA), while the principle of estimation of FSH and LH combine a one step enzyme immunoassay sandwich method with a final fluorescent detection (ELFA). Results were calculated by the instrument in relation to the calibration curve stored in memory of device, and then printed the results . The same procedure was applied to T3, T4 and FSH hormones are determined by using VIDAS T3, VIDAS T4 and VIDAS FSH kits.

\subsection{2:- Procedure:}

1- "The required reagents were removed from the refrigerator and were allowed to come to room temperature for $30 \mathrm{~min} "$.

2- One FSH strip and one FSH SPR were used from the kit for each sample, (control) to be tested. The storage pouch was resealed after the required SPR removed".

3- FSH on the instrument test code was selected. The calibrator must be identified by (S1), and tested. "If the control needed to be tested, it should be identified by C1".

4- The samples, the calibrator and the control were mixed, using a vortex .

5- $200 \mu 1$ of sample was pipetted, calibrator or control into the sample 
6- VIDAS-SPRs and strips were inserted into the positions indicated on the screen. The color labels with three letters assay code on the SPRs and the reagent strip should be matched.

7- The assay processing was started as directed in the Operator's Manual.

8- "After the assay was completed, the SPRs and strips were removed from the device" .

All the assay steps are performed automatically by the instrument. The assay will be completed within one hour. The same procedure was carried out on the LH, T3 ,T4 , TSH and PRL .

The levels of hormonal assays for the subjects were compared with the next normal range:, FSH $=3.9-12 \mu \mathrm{IU} / \mathrm{ml}, \mathrm{LH}=1.5-8 \mu \mathrm{IU} / \mathrm{ml}, \mathrm{FT3}=0.95-2.5 \mathrm{n} . \mathrm{mol} / \mathrm{L}$, FT4 $=60-120 \mathrm{n} . \mathrm{mol} / \mathrm{L}, \mathrm{TSH}=0.25-5 \mu . \mathrm{IU} / \mathrm{ml}$ and $\mathrm{PRL}=2-25 \mathrm{ng} / \mathrm{ml}$

\section{3:4:- Statistical analysis:}

Statistical analysis was done by Statistical Analysis System (SAS) software 2004 was used to the

effect of difference factors in traits in this study. "Least significant difference (LSD) test was used to the significant compare between means". A p-value $<0.05$ was considered statistically significant"[10].

\section{4:- Results and discussions :}

Serum TSH ,FT3 and FT4 levels of patients women and control group are presented in table (1), the results reveled that the TSH serum were higher significantly $(\mathrm{p}<0.01)$ increased when compared with control group. The FT3 and FT4 levels were significantly $(\mathrm{p}<0.05)$ decreased in patients women respectively when compared with control group . 
Table 1: Levels of TSH ,FT3 and FT4 in women with hypothyroidism.

\begin{tabular}{|c|c|c|c|}
\hline \multirow[b]{2}{*}{ Hormones } & \multicolumn{2}{|c|}{ Mean \pm SE } & \multirow[b]{2}{*}{ LSD } \\
\hline & $\begin{array}{c}\text { Healthy control } \\
(\mathbf{n}=10)\end{array}$ & $\begin{array}{l}\text { Hypothyroidism } \\
\text { Patients }(\mathrm{n}=30)\end{array}$ & \\
\hline TSH $\mu \mathrm{IU} / \mathrm{ml}$ & $3.11 \pm 0.71$ & $20.19 \pm 3.65$ & $3.39 * *$ \\
\hline T3 n. mol/L & $2.00 \pm 0.11$ & $1.18 \pm 1.96$ & $11.216^{*}$ \\
\hline n. $\mathrm{mol} / \mathrm{L}$ & $88.21 \pm 6.22$ & $46.66 \pm 4.11$ & $4.111 *$ \\
\hline
\end{tabular}

$*(\mathrm{P}<0.05), * *(\mathrm{P}<0.01)$, TSH : Thyroid Stimulating Hormone, T3: Triiodothyronine , SE : Standard error, LSD : Least Significant Differences.

T4: Thyroxin ,

The variation in the mean values of serum TSH , FT3 and FT4 levels in this study were common in hypothyroidism because the thyroid gland fails to production a sufficient amount of FT3 and FT4, in other hand ; there were increase in levels of TSH that mean the patients suffering with hypothyroidism [11].

Acquired hypothyroidism can result from many reasons like previous injury of thyroid or by exposure to environmental radiation [12]. Nearly 61 different mutations have been reported in TPO gene [13]. Thyroid peroxidase it is an enzyme that responsible of iodide oxidation and transport it to follicle cavity by anion transport called pandrin, the mutation in TPO gene may be prevent the thyroid peroxidase to binding with the heme or the unable of enzyme to binding with thyroglobulin[14].

The menstrual irregularities observed in $70 \%$ of patients hypothyroidism which is nearly similar to the observed by Gosuami and his team [15]. The authors reported the association between menstrual disturbance and high levels of TSH that impact on ovulatory and decrease the fecundity[16] . Hypothyroidism may be impact on fertility by changing the estradiol (E2) metabolism and by reduction of the sex hormone binding globulin (SHBG) that resulting in increase ovarian production with anovulation, both pathways lead to abnormal feedback at the pituitary; therefore the disturbance of thyroid hormone lead to incidence with menorrhagia by reduction of coagulation factor VII ,VIII , IX and [17].

Gonadotropins hormones were included in this study, FSH was significant ( $p$ $<0.05$ ) decreased in patients with hypothyroidism when compared with control group. The LH levels recorded increased in patients with non significantly in patients with hypothyroidism . Prolactin levels were obtained raveled a significantly $(\mathrm{p}<0.05)$ increased in patients with hypothyroidism table (2). 
Table (2) : Gonadotropins and prolactin hormones levels

\begin{tabular}{|c|c|c|c|}
\hline \multirow{2}{*}{ Hormones } & \multicolumn{2}{|c|}{ Mean \pm SE } & \multirow{2}{*}{ LSD } \\
\cline { 2 - 3 } & $\begin{array}{c}\text { Healthy control } \\
(\mathbf{n = 1 0})\end{array}$ & $\begin{array}{c}\text { Hypothyroidism } \\
\text { Patients }(\mathbf{n}=\mathbf{3 0})\end{array}$ & \\
\hline $\mathrm{PRL} \quad \mathrm{ng} / \mathrm{ml}$ & $12.73 \pm 1.44$ & $31.44 \pm 9.77$ & $12.678^{*}$ \\
\hline $\mathrm{FSH} \quad \mu \mathrm{IU} / \mathrm{ml}$ & $9.88 \pm 0.77$ & $5.52 \pm 1.01$ & $3.567^{*}$ \\
\hline $\mathrm{LH} \quad \mu \mathrm{IU} / \mathrm{ml}$ & $8.99 \pm 188$ & $11.26 \pm 288$ & $13.391 \mathrm{~ns}$ \\
\hline
\end{tabular}

* $(\mathrm{P}<0.05)$, FSH : Follicular Stimulating Hormone, PRL: Prolactin , LH: luteinizing hormone, SE : Standard error, LSD : Least Significant Differences.

Hypothyroidism interfere with normal pulastile gonadotropin realizing hormone $(\mathrm{GnRH})$ production , normal follicular development and ovulation the alteration of LH can resulting in menstrual disturbance including un ovulatory [18]. In the cell the thyroid hormone synergize with FSH to stimulate granolusa cell function and morphological differentiation, also facilitate FSH mediated LH/Human chorionic gonadotropin(hCG) receptors induction; therefore, the inadequate hormone lead to gonodal dysfunction [19] .

Hyperprolactinemia may be caused by increased of TSH concentration have been collaboration in ovulatory defect. "The morphological changes observed in the follicles in women with hypothyroidism can be caused by higher prolactin secretion that may block both production and action of gonadotropins" [20].

\section{5:- Conclusion :}

In this study we can conclude three main facts :

1- The measurement of thyroid hormone and prolactin are very important to identify the infertility .

2- Hyperprolactinemia and hypothyroidism are the main cause of infertility.

3- Hyperprolactinemia and hypothyroidism commonly related and synergized to ovulatory failure. 


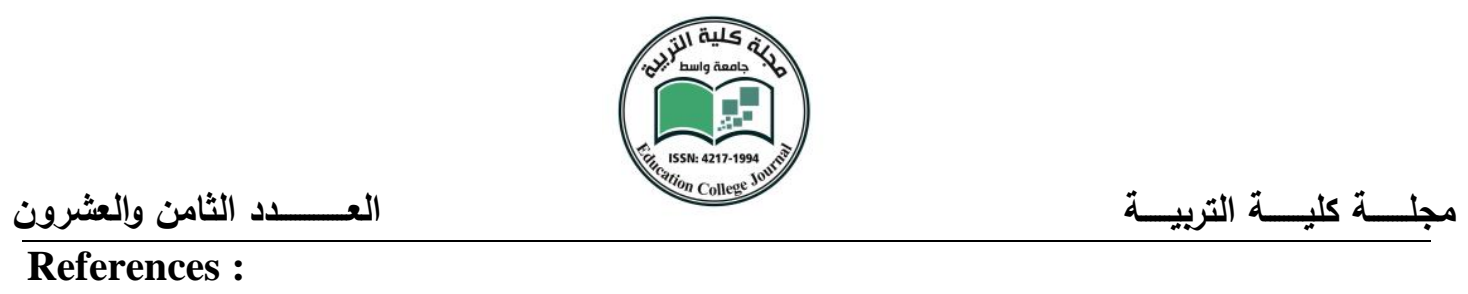

1- Aoki, Y.; Belin, R .M.; Clickner, R.; Jeffries, R.; Phillips, L. and Mahaffey, K. R. (2007). Serum TSH and total T4 in the United States population and their association with participant characteristics. Thyroid. Dec, 17(12):1211-1223.

2- Poppe,k. (2004). Female infertility and the thyroid.Res. Clinic Endoc \& Metab; 18( 2) Pp 153165

3-Gerhard, I.; Becker, T.; and Eggert-Kruse, W.(1991).Thyroid and ovarian function in infertile women. Hum Repro, 6, 338-345.

4-Bjoro, T. ; Holmen, J.; and Kruger, O.(2000). Prevalence of thyroid disease, thyroid dysfunction and thyroid peroxidase antibodies in a large, unselected population. The Health Study of NordTrondelag European. J. Endocrinol, 143: 639-647

5- Goldsmith, R .E.; Sturgis, S.H.; Lerman, J.; and Standburg, J.B. (1952).The menstrual pattern in thyroid disease. Journal of Clinical Endocrinol. Metab, 12: 846-855

6- LaFranchi, S.H.; Haddow, J.E.; and Hollowell, J. G.( 2005). Is thyroid inadequacy during gestation a risk factor for adverse pregnancy and developmental outcomes? Thyroid ,15:60-71.

7- Poppe, K. and Glinoer, D. (2003). Thyroid autoimmunity and hypothyroidism before and during pregnancy. Hum Reprod Update , 9:149-161.

8- Longcope, C.; Abend, S.; Braverman, L.; and Emerson, C.H. (1990). Androstenedione and estrone dynamics in hypothyroid women.J. Clin. Endocrinol . Metab , 70, 903-907

9- Macklon, N.S.; and Fauser, B.C. (2000) . Regulation of follicle development and novel approaches to ovarian stimulation for IVF. Hum.Reprod. Update, 6(4), Pp 307-312.

10- Statistical Analysis System . (2004) . SAS / STAT Users Guide for Personal Computers. Release 7.0. SAS Institute Inc., Cary, NC., USA. .

11- Kek.P.C.;Ho.S.C. and Khoo.D.H.(2003).Subclinical thyroid disease. Singapora .

Med.J.44(11):595-600.

12- AL-Ramahi,I.J.(2011). Molecular and Genetic Study in samples of Iraqi patients with Thyroid Disorders. Gen. Eng and Biotech Inst Postgrad Stud. Iraq, PhD thesis .

13- Ris- Stalpersa,C,and Bikker.H. (2010). Genetics and phenomics of ypothyroidism and goiter due to TPO mutations: Mol.Cell Endocrinol; 322 . Pp:38-43 
14- Carrasco, N. (2005). Thyroid hormone synthesis - thyroid iodine transport. In The Thyroid, 9th Edition, L.E. Braverman and R.D. Utiger, eds. (Philadelphia ,Pennsylvania, USA: Lippincott Williams \& Wilkins), 37-52

15- Binita, G.; Suprava, P .; Chatterjee, C.; Koner, B.; and Alpana,S.( 2009). Correlation of Prolactin and Thyroid Hormone Concentration with Menstrual Patterns in Infertile Women . $J$ Reprod Infertil, 10(3):207-212

16- Poppe,K., Velkeniers, B., and Glinoer,D. (2007). Thyroid disease and female reproduction . Clinic Endocrinol, 66:309-321.

17- Ansell, J.E.(1996). The blood in the hypothyroidism. In Braverman L and Utiger R (eds) Werner and Ingbar's the Thyroid, a Fundamental and Clinical Text, (seventh ed.) Philad: Lippin. Raven, 821-825.

18- Wakim, A.N.; Polizoto, S.L; and Buffo, M.J.(1993). Thyroid hormones in human follicular fluid and thyroid hormone receptors in human granulosa cells. Fert . Ster,59:1187-1190.

19- Maruo, T., Matsuo, H., and Mochizuki, M.(1991). Thyroid hormone as a

biological amplifier of differentiated trophoblast function in early pregnancy. Acta. Endocrinol, 125:58-66

20- Armada, D. L.; Carvalho, J.J.; Breitenbach, M.M.; Franci, C.R.; and Moura, E.G.(2001). Is the infertility in hypothyroidism mainly due to ovarian or pituitary functional changes? Braz J Med Biol Res,34 (9):1209-1215. 